Варакута Марина Іванівна, кандидат мистецтвознавства, доиент кафедри „, Історія та теорія музики” Дніпропетровської академії музики ім. М. Глінки тел. (097) 998 - 78 - 99 e-mail: amilomarina@i.ua

Суміна Катерина Борисівна, магістрант кафедри „Хорове диригування” Дніпропетровської академії музики ім. М. Глінки тел. (095) 761 - 62 - 28 e-mail:ket_sumina@mail.ru

\title{
ОСОБЛИВОСТІ ВИКОРИСТАННЯ ЗНАМЕННОГО РОЗСПІВУ В ДУХОВНИХ ТВОРАХ ІРИНИ ДЕНИСОВОЇ (на прикладі Херувимських пісень g-moll та e-moll)
}

Мета статті - проаналізувати регенерацію традицій знаменного розспіву та їх включення в сучасний церковно-хоровий простір, які $\epsilon$ важливим фактором професійного формування майбутнього хорового диригента. У статті розглядаються особливості використання знаменного розспіву в контексті сучасного сприйняття. Методологія дослідження визначена комплексним музикознавчим та історико-типологічним аналізами. Наукова новизна статті полягає у розкритті особливостей використання знаменного розспіву в Херувимських піснях композитора Ірини Денисової. У публікації висвітлюється художня своєрідність, творча самобутність композиторської обдарованості майстрині у період до прийняття чернечого постригу та вже після ствердження композиторкою шляху монахині. Висновки. Застосування знаменного розспіву може бути тільки в його гармонізації, не в аранжуванні і навіть не в обробці, тому що їх прийоми допускають проведення основної теми в різних партіях, а подібне „поводження” зі знаменним розспівом є неприпустимим. Особливості використання знаменного розспіву полягають в тому, 
щоб не вийти за рамки інтонаційно-емоційної сфери самого розспіву гармонізуючи його. У подібній обмеженості композитор, який гармонізує знаменний розспів може збагатити його за рахунок динаміки, ритміки, плагальних гармоній, але кардинально, значимо й істотно тільки за допомогою фактурно-гармонічних перетворень, звідки і з'являються терміни „фактуризація” i „гармонізація”. Процес гармонізації знаменного розспіву Ірини Денисової i монахині Іуліанії (Денисової) хоч і не значні, але має відмінності. Гармонізація написана після прийняття чернечого постригу (Херувимська e moll) відрізняється точною традиційністю, строгістю форми викладу музичного матеріалу, в піснеспіві вже не відчувається прагнення до концертності, а $\epsilon$ тільки стан молитовності.

Ключові слова: знаменний розспів, гармонізація, Херувимська пісня, підголоскова фактура, монодія, діатоніка.

Варакута Марина Ивановна, кандидат искусствоведения, доцент кафедры „История и теория музыки” Днепропетровской академии музыки им. М. Глинки

Сумина Екатерина Борисовна, магистрант кафедры „Хоровое дирижирование” Днепропетровской академии музыки им. М. Глинки

Особенности использования знаменного распева в духовных сочинениях Ирины Денисовой (на примере Херувимских песен g-moll и e-moll)

Цель статьи - проанализировать регенерацию традиций знаменного распева и их включение в современное церковнохоровое пространство, которые являются важным фактором профессионального формирования будущего хорового дирижера. В статье рассматриваются особенности использования знаменного распева в контексте современного восприятия. Методология исследования определена комплексным музыковедческим и историко-типологическим анализами. Научная новизна статьи заключается в раскрытии особенностей использования знаменного распева в Херувимской песни композитора Ирины Денисовой. В публикации освещается художественное своеобразие, творческая оригинальность композиторского дарования мастера в период до принятия монашеского пострига и уже после утверждения 
композитором дороги монахини. Выводы. Применение знаменного распева может быть только в его гармонизации, не в аранжировке и даже не в обработке, потому что их приёмы допускают проведение основной темы в различных партиях, а подобное поведение со знаменным распевом является непозволительным. Особенности использования знаменного распева состоят в том, чтобы не выйти за границы интонационно-эмоциональной сферы самого распева гармонизируя его. В подобной ограниченности композитор, который гармонизирует знаменный распев может обогатить его за счёт динамики, ритмики, плагальных гармоний, но кардинально, значимо и существенно только с помощью фактурногармонических изменений, откуда и появляются термины „фактуризация” и „гармонизация”. Процесс гармонизации знаменного распева Ирины Денисовой и монахини Иулиании (Денисовой) хотя и не существенные, но имеют отличия. Гармонизация, написанная после принятия монашеского пострига (Херувимская e-moll) отличается точной традиционностью, строгостью формы изложения музыкального материала, в песнопении уже не ощущаются стремления к концертности, а есть только состояние молитвенности.

Ключевые слова: знаменный распев, гармонизация, Херувимская песнь, подголосочная фактура, монодия, диатоника.

Varakuta Maryna, $\mathrm{PhD}$ in Arts, associated professor of the „History and Theory of Music” chair, Dnipropetrovsk Music Academy after Mikhail Glinka

Sumina Katerina, graduate student of the chair „Choral conducting" of Dnipropetrovsk Music Academy after Mikhail Glinka

Features of the using of the banner chant in the spiritual writings of Irina Denisova (on the example of the Cherubic songs g-moll and e-moll)

The purpose of the article is to analyze the regeneration of the traditions of the banners and their inclusion in the contemporary church choir space, which are an important factor in the professional formation of the future choral conductor. The article deals with the peculiarities of the use of the banners in the context of modern perception. The methodology of the study is determining by complex musicological and historical-typological analyzes. The scientific novelty of the article 
consists in revealing the peculiarities of the use of the famous chant in the Cherubic song of the composer Irina Denisova. The artistic peculiarity, creative originality of the composer's endowment of master in period before taking of monastic vows and after affirmation by composer of monasticism's way is revealed by investigator in this article. Conclusions. The employing banner chant can be only in its harmonization, not at the arrangement and even not at the handling, because their capabilities allows carry out mean tune in different parts, but the actions like that with banner chant is not permitting. The features applying of banner chant consists in the next, that not go off from limits of internationally emotional area yourself chant to harmonizing it. Composer, in the like limitation, which harmonizes banner chant can enrich its at the expense of dynamic, rhythmic, plagal harmony, but cardinally, master can upgrade amazingly significantly and essentially yourself creation only by means of the structurally harmonic modifications, from appearing the concepts structuration and harmonization. There are distinctions concerning the process of harmonizing for banner chant by Irina Denisova and by nun Juliana (Denisova) nevertheless not substantial. The precise traditionalism, strictness of the form for presentment of musical material differs harmonization, compositions wrote after the accepting of monastic vow (the Cherubic e-moll). The rush to concert emotions do not feeling in the chant yet, but there is only condition of prayerfulness.

The key words: banner chant, harmonization, Cherubic song, subvoice structure, monody, diatonics.

Постановка проблеми. Як відомо, хорове мистецтво має специфічну особливість - синтетичний характер (поєднання музики i слова). Знаменний розспів як окремий розділ у галузі історії хорового мистецтва також $\epsilon$ синтетичним поняттям. Структура теми статті включає у себе поняття „знаменний розспів”, яке вміщує не тільки суто музичну сторону, але й теологічну (богословську). На цих засадах, власне, і грунтується ця публікація. Відродження давніх традицій знаменного розспіву та перенесення (реставрація) їх у сучасний хоровий простір є значущою складовою логічного, історично-цілісного формування світогляду професійного музикознавця та хорового диригента зокрема. 
Актуальність дослідження. Розгляд особливостей використання знаменного розспіву в духовних творах є актуальним, тому що в наш час деякі монастирі, які шанують традиції стародавнього співу, відроджують їх. Також актуальністю дослідження означеної теми постало вивчення духовних творів I. Денисової, які на сучасному етапі розвитку музичної культури $є$ маловивчені.

Огляд літератури. Питання про церковні твори Ірини Денисової у вітчизняному музикознавстві постають мало висвітленою темою наукових досліджень сьогодення. Наукові статті Ю.В. Воскобойнікової [1], в яких автор розглядає специфіку хорової творчості монахині Іуліанії (Денисової) та іiі місце в сучасній церковно-співацькій практиці, торкаються питань етики та естетики богослужбового співу. Розглядається зокрема роль духовних основ та внутрішніх спрямувань композитора у створенні хорових творів на канонічні тексти й їх вплив на художній результат. Також Ю.В. Воскобойнікова аналізує основні принципи творчої роботи Святкового хору Свято-Слисаветинського монастиря (м. Мінськ) та діяльність його регента монахині Іуліанії (Денисової) [2].

В. Густова у своєму аналітичному есе „Херувимская песнь знаменного распева в гармонизации Ирины Денисовой” [3, 99-101] висвітлює загальні відомості про знаменний розспів, робить деякий аналіз хорової партитури Херувимської пісні g-moll, спираючись на власну музикознавчу ерудицію, поєднує іiі 3 особистісним ставленням до композиторки, як до товариша, як до керівника колективу в якому перебуває.

Мета статті - проаналізувати та прослідкувати особливості використання знаменного розспіву у богослужбових творах монахині Іуліанії (Денисової), систематизувати знання у сфері церковно-хорового мистецтва на сучасному етапі.

Об'єктом дослідження є Херувимські пісні g-moll та e-moll, a предметом - особливості використання знаменного розспіву в щойно означених Херувимських піснях.

Виклад основного матеріалу дослідження. Ірина Денисова (білоруський композитор, диригент) є регентом святкового хору Свято-Слисаветинського жіночого монастиря міста Мінська, де вона прийняла чернечий постриг з ім'ям Іуліанія. Ірина Денисова - 
автор понад 150 церковних піснеспівів, гармонізацій та обробок. Надрукований видавництвом Свято-Слисаветинського монастиря нотний збірник ऑii творів „Пение всеумиленное”, що включає піснеспіви Божественної Літургії та Всенічного бдіння, а також паралітургічні піснеспіви, користується попитом серед православних музикантів Білорусі, Росії та України. „Беседы о пении в Церкви” Ірини Денисової розкривають зміст та історію музичної частини богослужіння (надруковані в газеті Мінської Спархії „Церковне слово”).

У власних духовних творах композитор звертається саме до гармонізації знаменного розспіву. В інтерв'ю монахиня Іуліанія (Денисова) піднімає ряд питань: що ми можемо зараз зробити для богослужбового співу? Що корисного може запропонувати людина XXI століття знаменному розспіву?

Ірина Денисова у своїй розповіді-інтерв'ю цитує Бориса Кутузова, який у власній книзі „Знаменный распев - поющее богословие” зазначає: „Задача современного клироса [композитора], практикующего знаменное пение, обеспечить певческое отправление Богослужения сегодня и для сегодняшних прихожан, а не пытаться искусственно стилизовать песнопения под 14-15 века" [4].

Учасниця Святкового хору Свято-Слисаветинського монастиря, викладач гімназії-коледжу при Білоруській академії музики Віра Густова у своєму аналітичному есе зазначає: „Гармонизация знаменного распева [...] традиция многовековая, творчески неисчерпаемая. Вслушиваясь в „Херувимскую” И. Денисовой, почему-то проникаешься ощущением, что речь идет не о гармонизации - но о слышании знаменного распева в его уникальной красоте, глубине, надмирности..." [3, 99].

Для стародавнього розспіву саме гармонізація $\epsilon$,золотою” серединою сучасного композиторського рішення. Зберігаючи монодію (справжній розспів), слід враховувати сучасну специфіку сприйняття музичного матеріалу виконавцем i слухачем. Гармонізації знаменного розспіву Ірини Денисової спираються, як зазначає композиторка, на теорію Олександра Амерханова, який у власній праці „Проблемы гармонизации и обработки одноголосных распевов” висуває низку законів для створення моделі сучасного твору на основі розспіву, яке мало б право називатись піснеспівом. 
Отже, О. Амерханов пропонує наступні закони гармонізації розспіву:

1) від „канта” - запозичувати чоловічий склад хору;

2) від гармонізації всіх періодів взяти синхронне вимовляння тексту всього хору.

3) використання помірної теситури (тут I. Денисова, доповнюючи, пояснює, що людська мова, а значить і молитва не вимовляються у високій теситурі, композитор спирається на природний фактор людського голосу);

4) від ладо-гармонійної опори розспіву - взяти переважання діатоніки;

5) постійний емоційний стан (монахиня Іуліанія (Денисова) уточнює в інтерв'ю, в одному піснеспіві має бути один стан, отже, випливає питання про музичну форму. Форма піснеспівів повинна бути концентричною або спиралеподібною;

6) від народної протяжної пісні:

а) можливість ускладнювати церковний лад ладами народної музики;

б) свідома відмова від використання оборотів D7 - Т (взагалі, застосування D7 i його обернень - в рідкісних випадках, протиставляючи цьому опору на плагальність);

7) наближення інтонацій підголоскових партій до інтонацій самого розспіву [5].

Спираючись на перераховані вище параметри, ми б хотіли розглянути особливості гармонізації знаменного розспіву на прикладі двох Херувимських пісень - це „Херувимська пісня” знаменного розспіву (е-moll) (2010) та „Херувимська пісня” знаменного розспіву (g-moll) (2000).

Херувимська пісня - це богослужбовий, одночастинний твір, який завжди містить два розділи. Два розділи відокремлені один від одного молитвами-репліками, тобто речитацією священнослужителя.

Перші розділи пропонованих Херувимських пісень написані в концентричній формі, а другі - у наскрізно варіантній.

Розспів Херувимської пісні (e-moll) - виключно діатоніка, яка $\epsilon$ прикладом того, як ускладнюється натуральний діатонічний звукоряд дорійським ладом, що запозичене від жанру протяжної російської пісні. Стародавній знаменний розспів у окресленій 
Херувимській пісні проводиться тільки в одній партії, що $є$ принциповою особливістю. Діапазон розспіву в межах квінти. Поступовий рух мелодії розспіву, відсутність стрибків й оспівування основних ступенів $є$ ознаками древньої аскетичності.

Протягом усього піснеспіву мажорний тризвук VII ст. зустрічається тричі. Ця потрійність обгрунтована, тому що нею пронизане все православ'я. У гармонізації в підголоскових партіях, фрагментарно узятих із самого розспіву, простежуються інтонації протяжної пісні. В основі інтервального рішення - велика кількість терцій і секст. У піснеспівах переважає акордова фактура, але зустрічається і підголоскова.

Виконавський склад Херувимської пісні e-moll - це мішаний чотириголосний хор 3 divissi в партії басів. Херувимська пісня g-moll також написана для мішаного чотириголосного хору, але divissi зустрічається в усіх хорових партіях, крім партії сопрано.

Генеральні кульмінації цих Херувимських пісень відбуваються у кінці твору - на словах „Алілуя”, які мають найголовніший сенс перебування всіх людей на землі - завжди прославляти й дякувати Господу. Кульмінації досягаються 3 допомогою зміни динаміки $f f$, ущільнення фактури (divisi у партіях басів, тенорів і альтів), різноманітності ритміки, завдяки якій створюється враження дзвіниці.

Теситурні умови не створюють особливого кульмінаційного ефекту, тому що завдання стоїть у помірній теситурі, близькій до природного мовлення. Від гармонізацій усіх періодів, саме у цих творах присутня синхронна вимова молитовного тексту.

Таким чином, можна сміливо визначити, що вищеокреслена гармонізація знаменного розспіву суворо витримана відносно усіх щойно зазначених правил.

У „Херувимській пісні” g-moll початкове проведення розспіву звучить в партії сопрано, так само, як і в Херувимській е-moll. Тут мелодія піднеслась, немов відриваючись від усього земного на витриманому остинатному фоні, у партіях басів i тенорів (чоловічий склад хору - від канта). Лише партія баритона вступає в інтонаційний діалог з партією сопрано. У партії альтів паузи, отже, голоси розташовані широко, що передає відчуття простору, обсягу, який можна порівняти 3 древніми храмовими склепіннями. В усій першій частині нерідко зустрічається стрічкове багатоголосся, 
характерне для російської пісенності. Змістовна серцевина III підрозділ першого розділу Херувимської пісні полягає у рядках „Трисвятую песнь припевающе”. Від означеного моменту автор у гармонізації змінює фактурну концепцію, відбувається переміна динаміки, включається компліментарна ритміка. Гармонізуючи цей фрагмент, автор не тільки використовує інтонації розспіву для гармонізації, але й складає їх, максимально наближаючи до інтонацій самого розспіву. Завдяки використанню відповідних інтонацій кожна $з$ партій розвивається лінеарно. Автор, слідуючи за молитовним текстом на словах: „Всякое ныне житейское отложим попечение....." - допомагає максимально налаштуватись на молитву 3 допомогою згортання голосів і насамкінець, залишаючи лише один піднесений розспів і гармонічний фон.

У другому розділі Херувимської пісні g-moll відбувається розгортання голосів, розспів передається партії тенора. Ірина Денисова пояснює це композиторське рішення у власних авторських ремарках під час інтерв’ю: „Сделала это умышленно, чтобы прозвучал мужской хор, как образ воинов Христовых" [5]. Фоном тепер є жіночі голоси, в яких чутно проростання російської протяжної пісні з присутнім веденням співу в сексту. Використання тільки плагальних зворотів простежується у всій гармонізації, однак тільки один раз автор використовує D7 із секстою. Віра Густова писала: „...возникший аккорд („шопеновская” доминанта) стал знаком нам, музыкантам, своей трепетностью и особой лиричностью. И вот такое проявление личностного, интимного (если можно так сказать) начала в кульминации незримо и смиренно приближает надмирный знаменный распев к сегодняшнему слабому, но очень любящему Бога человеку" [5].

Отже, гармонізуючи давній розспів (не авторський) композитор робить звучання, адаптоване для сучасного слухача.

Крім акордово-гармонічної вертикалі, автор використовує i підголоскову техніку, але не підголоскову поліфонію. І. Денисова акцентує на цьому увагу у своєму інтерв'ю, пояснюючи, що поліфонія і молитва непоєднувані речі. Таким чином, монахиня Іуліанія (Денисова) імовірно висуває термін не стільки гармонізація знаменного розспіву, а фактуризація.

Висновки. Використання знаменного розспіву може бути тільки в його гармонізації, не в аранжуванні й навіть не в обробці, 
тому що їх прийоми допускають проведення основної теми у різних партіях, а подібне „поводження” зі знаменним розспівом $\epsilon$ не припустимим. Особливості використання знаменного розспіву полягають в тому, щоб не вийти за рамки інтонаційно-емоційної сфери самого розспіву, гармонізуючи його. У подібній обмеженості композитор, який гармонізує знаменний розспів, може збагатити його за рахунок динаміки, ритміки, плагальних гармоній, але кардинально, значимо й істотно тільки за допомогою фактурногармонійних перетворень, звідки і з'являються терміни „фактуризація” та „гармонізація”.

Гармонізація знаменного розспіву Ірини Денисової і монахині Іуліанії (Денисової) має, хоч і не значні, але ж певні відмінності. Гармонізація написана після прийняття чернечого постригу (Херувимська e-moll) відрізняється точною традиційністю, строгістю форми викладу, в піснеспіві вже не відчувається прагнення до концертності, а є лише стан молитовності. Глибше простежується архаїчність та ортодоксальність.

Перспективи дослідження означеної теми обумовлюються аналітичним, змістовно-аксіологічним зверненням науковців до значно ширшого кола творінь майстрині, композиторський доробок якої постає надзвичайно актуальним у часи сьогодення.

\section{Список використаних джерел і літератури:}

1. Воскобойникова Ю.В. О хоровом творчестве монахини Иулиании (Денисовой) в контексте современной церковно-певческой культуры // Весник БДАМ: сб. науч. ст. Минск: БДАМ, 2013. Вып. 22. С. 99-106.

2. Воскобойнікова Ю.В. Принципи богослужбового співу Святкового хору Свято-Слисаветинського монастиря (м. Мінськ, Білорусь) // Культура України: зб. наук. ст. Харків: ХДАК, 2014. Вип. 45. С. 284-291.

3. Густова В. Херувимская песнь знаменного распева в гармонизации Ирины Денисовой. Аналитическое эссе // И.В. Денисова Собрание песнопений. Литургия. Минск, 2015. С. 99-101.

4. Амерханов А. Проблемы гармонизации и обработки одноголосных распевов. http://ruskline.ru (дата звернення 07.09.2017)

5. Группа творчества монахини Иулиании (Денисовой). https://vk.com/videos (дата звернення 05.09.2017) 


\section{References:}

1. Voskobojnikova, Ju.V. (2013). About the choral creativity of the nun of Juliana (Denisova) in the context of contemporary church and singing culture. Vesnik BDAM, 22, 99-106 [in Russian].

2. Voskoboinikova, Yu.V. (2014). Principles of liturgical singing of the Festive Choir of St. Elizabeth Monastery (Minsk, Belarus). Kultura Ukrainy, 45, 284-291 [in Ukrainian].

3. Gustova, V. (2015). Cherubic song of the banner chant in the harmonization of Irina Denisova. Analytical essay. I.V. Denisova Sobranie pesnopenij. Liturgija, 99-101 [in Russian].

4. Amerhanov, A. (2001). The problems of harmonization and processing of singles chants. Retrieved from http://ruskline.ru [in Russian].

5. The group of the creation by nuns of Juliana (Denisova). Retrieved from https://vk.com/videos [in Russian]. 